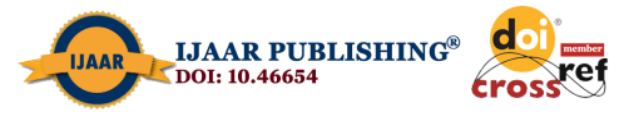

International Journal of Advanced Academic Research (Social and Management Sciences) | ISSN: 2488-9849

Journal DOI: 10.46654/ij.24889849

Vol. 6, Issue 10 (October, 2020) | www.ijaar.org

Article DOI: 10.46654/ij.24889849.s61031

\title{
EFFECT OF EXTERNAL AUDIT FEES DETERMINANTS ON AUDIT FEES IN DEPOSIT MONEY BANKS IN NIGERIA (2009-2018)
}

\author{
Alajo, Frederick K. ${ }^{1}$ and Nzewi, U.C. ${ }^{1}$ \\ Department of Accountancy, \\ Nnamdi Azikiwe University, Awka, Nigeria. \\ Mail: fredko655@gmail.com; ugockwuonwa@yahoo.com
}

\begin{abstract}
The results from the empirical evidence on the effect of external audit fees determinants on audit fees are inconsistent and some are contradictory; ranging from positive, to negative, to statistical insignificant effect. Besides, few research works have been conducted on Nigerian deposit money banks in particular. This study thereby determined the effect of external audit fees determinants on audit fees of Nigerian deposit money banks. Specifically, the study ascertained the significant effect of client complexity and board size on audit fees of Nigerian deposit money banks. Ex-post facto research design will be adopted for the study. A sample of 15 banks will be selected from a population of 15 deposit banks quoted on the Nigeria Stock Exchange. Data for the study was obtained from annual published financial of the banks covering a period of ten years from 2009-2018. Multiple regression analysis was used to test the formulated hypotheses. Findings revealed that client complexity, and board size has positive influence on audit fees of Nigerian deposit money banks but the influence on board size is statistically significant while client complexity was insignificant. The researchers recommended that regulators of the auditing practice should adopt measures to regulate and monitor the audit pricing process in order to strike a balance and reduce over-charging and under-charging to enhance the independence of the auditor.
\end{abstract}

Keywords: Audit fees, Client complexity, and Board size 


\section{INTRODUCTION}

Auditing is a fundamental concept in accountancy profession. The amount charged by the professional accounting firm has attracted a great deal of concern among academic researchers and practitioners (Urhoghide \& Izedonmi, 2015). According to International Standards on Auditing No.15 (2011), audit fees are the amount paid to financial auditors for the certification of financial statements. In other words, audit fees can be defined as the amounts of fees (wages) charged by the auditor for an audit task performed on the accounts of an enterprise (auditee). The determination of the audit fees is based on the contract between the auditor and the enterprise in accordance with time spent on the audit process, and the service required (Simunic, 1980). There is a growing trend in accounting in recent years about the issue of audit fees relating to how auditors determine the amount of fees charged for audit services. The full separation between ownership and management demands the need for appointment of an auditor charged with the responsibility of examining the financial statements prepared by client's management. The fee to be charged by the auditor for service or engagement within a given duration is very fundamental in auditing service (Urhoghide \& Izedonmi, 2015).

The external audit services and audit fees paid by companies to their auditors are obviously of interest to both companies and auditors: Companies are statutorily required to have their financial statements audited and want the fees they pay to be reasonable, auditors provide such services and want to ensure that the fees they charge are sufficient to enable a satisfactory service to be provided (Gist, 1992). In addition to companies and auditors, the shareholders in particular and the public in general are concerned that the audit fee is not set of such a level, (it is either too high or too low) it might undermine confidence in the audit opinion (Hassan, 2015). Furthermore, the level of audit fees and how they are determined are significant matters to both national and international professional accounting bodies to indicate the basis on which audit fees should be determined, the costs which should be covered by an audit fee, and the factors which should be taken into account when determining the audit fee. In addition these statements were also designed to restrict auditors from charging their fees on a basis which might be incompatible with the ethical values associated with the audit profession. Consequently, they seek to protect the auditors from losing their objectivity, and effectiveness as independent auditors (Hassan, 2015).

The amount of fees paid to external auditors is of great importance to a number of stakeholders that is why disclosure practices requires that such information be disclosed in the financial statements of companies (Kikhia, 2014; Hentati \& Jilani, 2013). While the determinants of audit fees are not new in literature, the significance of the determinants in pricing audit fees within a developing country context is limited. This study reviews factors pertaining to determinants of audit fees and an insight into the determinants of audit fees within a developing country context by focusing on listed companies in the Ghana Stock Exchange.

While the external audit fee is no different from other costs borne by the clients, the service received is hardly visible, with the only tangible "product" a relatively brief and standardized audit report (opinion) (Ask \&Holm, 2013). In this situation, clients would benefit from some external assurance that their fee is not disproportionate or out of proportion. Although much of 
the audit conducted by the external auditor is out of the sight of the audited firm, the latter derives satisfaction from the positive reviews received from the former regarding the latter's financial records. To the audited client, "transparency" of the auditing process or determinants of audit fees may result in additional satisfaction (Hentati \& Jilani, 2013; Kwong, 2011; Shafie, Che Ahmad \& Md Ali, 2007).

Consequently, the development of audit fee models should assist in providing benchmarks for assessing audit fees, which, in turn, should assist clients both in reviewing current fee levels as well as in better informing their choice of auditors (Alhassan, 2017). The amount of fees paid to external auditors is of great importance to a number of stakeholders that is why disclosure practices requires that such information be disclosed in the financial statements of companies (Kikhia, 2015; Hentati \& Jilani, 2013). Bedard and Johnstone (2010) pointed out that audit tenure is positively associated with the level of external audit fee. Moreover, they suggest that the closer association between external auditors and their clients can generate a financial dependence of auditors on their clients which threatens audit independence.

Most of studies revealed that client's size of business, international recognition; affiliation of audit firms (Big four firms) and profitability are significant determinants of audit fee (See Alhassan, 2017; Agbeja and Sokunle, 2016; Bogale, 2016; Belen, Roberto \& Antonio, 2014; Chijioke, Adeyemi, Obehioye, 2013). Despite this, some researchers found negative significant effect between audit fees and its determinants; client size, client profitability, audit size, client complexity, audit committee independence and board size, (see Hassan, 2014; Soyemi and Olowookere, 2013; Adeyemi, et al., 2013; Siregar, et.al, 2012). While the determinants of audit fees are not new in literature, the significance of the determinants in pricing audit fees within a developing country context like Nigeria is limited (Aliu et al, 2018; Ohidoa and Okun, 2018; Urhaghide and Izedonmi, 2015; Soyemi and Olowookere, 2013). Moreover, many studies have been focused on the market for audit profession and services in developed and developing countries.

The results from the empirical evidence on the determinants of external audit fees are inconsistent and some are contradictory; ranging from positive, to negative, to statistical insignificant effect. Besides, few research work have been conducted on Nigerian deposit money banks in particular; (Agbaje and Sokunle, 2016; Soyemi and Olowookere, 2013) and their studies focused on the role of external auditor in fraud prevention and client attribute on external audit fees charged by banks. It is against the above backdrop that the current study extends previous studies by presenting new evidence about the external audit fees determinants in Nigerian deposit money banks.

This study determines the extent determinants of audit fees affect external audit fees of Nigerian deposit money banks. Specifically, the study intends to achieve the followings;

1. To determine the effect of board size on audit fees of Nigerian deposit money banks.

2. To ascertain the effect of client complexity on audit fees of Nigerian deposit money banks. 
Journal DOI: 10.46654/ij.24889849

\section{REVIEW OF RELATED LITERATURE}

\subsection{Conceptual Framework}

\subsubsection{External Audit Fees}

Different studies have been conducted to explore the factors that determine audit fees charged by auditing firms. The knowledge of these factors is helpful for both clients and auditors because it leads to a better negotiation between client and auditor (Al-Harshani, 2008). Audit fee is determined on the basis of characteristics specific to auditing firm and client. Characteristics of client include: size of its business, complexity of its business and risk of the business However, engagement attributes are also significant determinants of audit fee (Kwong, 2011; Sundgren \& Svanstrom, 2013; Hentati \& Jilani, 2013).

Audit fee refers to the remuneration payable to an auditor for audit services rendered. In other words, an audit fee is a fee that a company pays an external auditor in exchange for performing an audit. The Ghanaian audit industry is regulated by Institutes of Chartered Accountants, Ghana (ICAG). Accountants have to be cautious when entering into negotiations for professional work to avoid any issue that can ruin their independent professional judgment (ICAG, 2006). The audit fee charged is influenced by auditor dependent factors: the reputation of the auditor, auditor experience, competition in the audit market (Hentati \& Jilani, 2013; Ask \& Holm, 2013; Castro et al. 2015). Audit fees is also determined by the clients' company factors such as company size, complexity of operations of the company, clients firm risk, and the profitability of the clients' firm (Joshi \& Al-Bastaki, 2000).

Hay, Knechel and Wong (2006) conducted a meta-analysis of the audit fee studies conducted up to year 2007. In their study, they discussed the audit fee determinants that have been used in all studies conducted regarding pricing of audit service. Results of the study show that auditors charge fee based on three factors. These are; client specific (client's business size, client's risk and client complexity), auditor specific (size of the firm) and engagement (busy season).

Moreover, information about determination of audit fees can be provided to legislators who set business regulations that are imposed on companies. In general, the external audit fee has four basic aspects: Determining the fee, selling the fee, billing the fee and collecting the fee. The current study is concerned with the first aspect which is the determination of audit fees. Moreover, this study focuses on the identification of the factors that enter into the determination of audit fees, factors which may directly affect the time of the audit work or indirectly the level of audit fees (Hassan, 2015).

While the external audit fee is no different from other costs borne by the clients, the service received is hardly visible, with the only tangible "product" a relatively brief and standardized audit report (opinion) (Ask \&Holm, 2013). In this situation, clients would benefit from some external assurance that their fee is not disproportionate or out of proportion. Although much of the audit conducted by the external auditor is out of the sight of the audited firm, the latter derives satisfaction from the positive reviews received from the former regarding the latter's financial records. To the audited client, "transparency" of the auditing process or determinants of 
audit fees may result in additional satisfaction (Hentati \& Jilani, 2013; Kwong, 2011; Shafie et al., 2007).

In point of fact, both US and UK are the original countries to investigate the matters related to external audit fees. Consequently, in researches on pricing of audit service determinants, both of the countries have been focused on: US (Bedard \& Johnstone, 2010; Callaghan et al, 2008) and the UK (Moizer, 1997; Pong, 2004). In addition, scholars have also taken companies of Australia (Carson et al, 2004; Carson \& Fargher, 2006), France (Gonthier-Besacier \& Schatt, 2007), India, Bangladeshi, and Pakistan (Ahmed and Goyal, 2005), Danmark (Thinggaard and Kiertzner, 2008), Bahrain (Joshi and Bastaki, 2000), Kuwait (Meshari, 2008) into consideration.

In most of the mentioned studies, relationships between external audit fees and some factors are usually found. Gonthier-Besacier and Schatt (2007) indicated that external audit fees paid by listed French companies have an important and significant association with audit size, audit risk and auditor size. Meanwhile, Joshi and Bastaki (2000) conclude that audit fees paid by Bahrain listed companies rely on size of the reporting entity, profitability, company risk, company complexity and providing non-audit services. Furthermore, Bedard and Johnstone (2010) pointed out that audit tenure is positively associated with the level of external audit fee.

Moreover, they suggest that the closer association between external auditors and their clients can generate a financial dependence of auditors on their clients which threatens audit independence. The study of Ahmed and Goyal (2005) examined the determinants of audit fees charged to listed companies in South Asia including Bangladesh, India and Pakistan. They show that auditor size and auditee size are the most important determinants of audit fees, but the results indicated that audit fees and auditee complexity are not associated. To sum up the above, audit fee structure has been displayed as complex by the empirical research of audit fee determinants in different countries. Nearly all research has shown connections between auditee size, auditee risk, and auditor size and audit fees. Research indicates that, in specific situations, investors may even trust companies that pay high audit fees. Furthermore, these results also show that the concern about audit independence impairment derived from high external audit fees is reasonable. Consequently, it is important to regulate audit rotation.

\section{Board Size}

Beasley (1996) finds that the larger boards are less effective in monitoring the financial reporting process which invariably results in the external auditor devoting more efforts in assessing the control environment of the company and hence a higher external audit fees. In contrast, Yatim, Kent and Clarkson (2006) found that external audit fees are not related with the board size. This is also consistent with Dillian (2007) who also found that board size is not significantly associated with external audit.

\section{Client Complexity}

Auditee complexity has been of interest in researching into determinants of audit fees. Audit fees are dependent on how long auditors have to spend for a particular audit engagement and this may therefore imply that companies with complexity will be charged higher audit fees. Result of 
Joshi \& Bastaki (2000); Gonthier-Besacier \& Schatt, 2007; Ahmed \& Goyal (2005) seem to be consistent with the view that auditee complexity has a significant relation with audit fees.

Complexity of the auditees can be measured by the number of branches and subsidiaries of the firm locally and internationally. Sandra and Patrick (1996) assert that, the more complex the client firm is, the greater the number and the more diversified the subsidiaries and operations are; which necessitate more audit work leading to a higher audit fees. Auditors of high complex firms often charge high audit fees in examining and evaluating the firms' financial statements. According to Sandra and Patrick (1996), foreign subsidiaries have to abide by a variety of legislative and proficient requirements for disclosure, which necessitate further audit testing, requiring more time and additional manpower to complete the audit process. This implies that, the companies have to bear additional charges for audit work.

Therefore, client's complexity has a positive correlation with the audit fees (Chan et al., 1993; Carson, Fargher, Simon \& Taylor, 2004). Complexity of audited firm is commonly examined in two aspects; that is complexity of operations and complexity of the financial statements composition. Consequently, the complexity of operations of the enterprise may lead to Complex transactions which will invariably require an auditor spending longer time and other resources in carrying out an audit task, and the consequence of this is high audit fees. In particular, Joshi and Al-Bastaki (2000) have shown that audit fees are positively associated with the number of subsidiaries in foreign countries. To buttress this assertion further, Gonthier-Besacier and Schatt (2007) and Semiu and Olayinka, (2010) found considerable evidences that suggest a positive association of firms' complexity and audit fees.

\subsection{Review of Empirical Studies}

Quite a number of studies have been carried out on auditing issues especially, on external audit fees and its determinants. Yuan, Indrit and Ann (2019) examined whether the clients of a merged audit firm have shortened report lag, increased audit fees, or reduced audit quality following the merger. These questions are important for a balanced investigation of a firm merger because regulators focus more on the downside of a merger than on its upside. Using a merger of audit firms in Hong Kong as a setting, this paper reports that clients of the merged firm have shorter audit report lag post-merger in the property industry in which the merged firm subsequently obtained more than one-half of the market share. Aliu, Okpanachi and Mohammed (2018) ascertained the relationship between audit fees and audit quality of listed companies in the downstream sector of the Nigerian petroleum industry. Secondary data used for the study was extracted from the annual reports of the selected companies for eight (8) financial years (20072014). Audit quality which is the dependent variable was regressed on audit fees alongside leverage and age as control variables using the binary logit regression method. Finding shows that audit fee has a negative significant relationship with audit quality, while leverage also has an inverse relationship but was not significant.

Ohidoa and Okun, (2018) examined the firms' characteristics and audit fees in Nigeria. The justification arose from the fact that, auditing profession has come under increased scrutiny over the years about the growing amount of fees paid by audit client and the contributing impact of 
such fees on auditor independence and the need to investigate the firms' factors that affect audit fees in Nigeria. And the statistical tool used in the study was Panel Least Square Regression with the aid of Eview 7.0 and SPSS 20. The study found that, auditor type, client's firm size, client's complexity, client's firm risk and audit committee independence have significant effect on audit fees, while firm's profitability has no effect on audit fees. Alhassan (2017) examined the determinant of audit fee with empirical evidence from the Ghana stock exchange. Specifically, the study examined audit fee determinant which included the client size, profitability measured by ROA, LOSS, client risk measured by debt ratio, YEAR (season) and MNC. Using the Simunic (1980) model, results in study indicate that ignorance of risk factor by the auditors may pose serious threat to fame and reputation of audit firm along with indication of feeble legal regime in Ghana. The results of the study have significant implications for auditors and firms in negotiating audit fees in Ghana. Agbeja and Sokunle (2016) investigated the role of external auditor in the prevention of frauds in the Nigerian Deposit Money Banks. Secondary data obtained from CBN and NDIC reports and bank databases were used. Ordinary Least Square method and Analysis of Variance (ANOVA) were employed. The results revealed that there was significant relationship between incidence of frauds and changes in banks deposit; incidence of non-performing loans consequent on fraud; bank contribution to the economy consequent on non-performing loans. Bogale (2016) determined the external audit quality and the various determinant factors those influence it. Specifically, the study used documentary analysis of companies' audited financial statements and personal inquiry with audit directors/officials of audit firms and company managers. The results of panel least square regression analysis show that certified audit professionals' and joint provision of audit and non-audit services have statistically significant and positive relationship with manufacturing share companies' external audit quality. Gholamreza and Samira, (2015) evaluated the present study deals with the evaluation of the relationship between auditing quality and the profitability in the companies accepted in Tehran's securities exchange market. The study findings show that generally there is a positive and weak relationship between the auditor size (auditor's good fame) and the auditor's tenure period and the profitability ratios. Shivaram, Suraj and Xin (2015) ascertained the determinants of audit quality; the study used a variation of Big $\mathrm{N}$ auditor, discretionary accruals, audit fees, accrual quality, going-concern opinions, or meet or beat the quarterly earnings target as a proxy for audit quality. The study provide evidence on the construct validity of these measures by evaluating whether they are able to successfully predict alleged audit deficiencies in engagements that are the subject of non-dismissed lawsuits and SEC's AAERs filed against auditors over the violation years 1978-2011. ICAS (2014) ascertained the influence of auditor independence, audit tenure and audit fee both partially and simultaneously on the audit quality of members of capital market accountant forum in Indonesia. The study used primary data that was collected via the distribution of questionnaires. Linear regression model was used to analyze the data and findings revealed generally that auditor independence, audit tenure and audit fee have a positive influence on audit quality. Nam and Ronen (2014) examined the relationship between audit fees as a proxy for auditor independence and audit quality of firms in New Zealand. Employing three multiple regression models for a sample of New Zealand companies. The study discovered that the provision of non-audit services by the auditors of a firm comprises the auditor's independence; abnormal audit fee change rate is negatively associated with audit quality and auditor's independence of the previous year impacts on the audit fee that is negotiated in the current year. Soyemi and Olowookere (2013) examined client attributes which 
significantly explain variations in the amount of external audit fees charged by bank auditors in Nigeria. Multiple OLS regression was adopted as the estimation technique on the panel data gathered through content analysis of annual reports and accounts of these banks over a 4-year post consolidation periods covering 2009-2012. The findings from this study reveal that bank size is also an important factor that is priced by bank auditors having shown a positive and significant influence accounting for $63 \%$ variations. Hartono, Subrato, Djumahir and Irianto (2013) examined the impact of firm characteristics proxy by firm age, profitability, leverage and firm growth on the audit quality and its impact on firm value in Indonesia. The research work sampled 110 firms listed in Indonesia Stock Exchange excluding all financial firms. Two-Stage Least Square (2 SLS) statistical model was utilized to analyze the relationship between firm size and audit quality. The study failed to document the period of the study, but the findings of the study show that firm age has significant and negative effects on audit quality. Chinwe and Chinwuba (2012) empirically examined the relationship between auditor's tenure, audit firm size and auditor's independence. The statistical technique used for this paper was the binary logistic regression. Findings revealed that auditor's tenure (TEN) does not compromise the independence of the auditors and audit firm size (AUD) does not also compromise the independence of the auditor. Siregar, et.al (2012) carried out their research in the Indonesian environment where regulators had made it compulsory to rotate the appointments of public accountants every three (3) years and the appointment of public accounting firms every five (5) years. Their results showed that mandatory auditor rotation did not increase audit quality; and that shorter audit tenure (both partner and firm level) did not also increase audit quality. Walid (2012) concluded that the size of the audit firm is important factor in affecting the amount of external audit fees in Lebanon. Presently, the Big 4 audit firms dominate the audit services market, and consequently, smaller firms face huge obstacles to enter the market of big companies. Moreover, the fee charged by big audit firms may be higher than that of non-big ones, due to the reputation impact and advantage of the former. Sharma (2011) examined whether there is a relationship between joint provision of audit and non-audit services and loss of auditors independent for publicly listed New Zealand companies in 2011 .Using discretionary accruals as an indicator of audit quality, the regression analysis discovered a significant positive relationship between lower abnormal accruals indicate that earnings quality is higher, which is a proxy of audit quality and the practice whereby external auditors providing non-audit service to its audit client. Bedard and Johnstone (2010) examined the relationship between audit partner tenure, audit planning and audit fees. The results reveal a strong association between audit fees and audit tenure of American companies. Furthermore, this study mentioned that the amount of audit fees for longer partner tenure is significantly positively associated with realization rates and audit partners contribute more audit effort in the first year of engagement. Meshari (2008) studied the factors influencing the amount of audit fees in Kuwait. Of particular interest is the investigation of the potential effect of the size of the audit firm on external audit fees. The study's results indicated that the audit firm size ("Big" audit firm vs "non-Big" audit firm) is not statistically influential in determining the amount of audit fees. Ettredge, Heintz and Scholz (2008) investigated client choice of industry auditors from among the Big 4 or 5 in an international setting. They found that international choice of home based Big 4 or 5 specialist auditors is positively associated with audit quality, capital intensity and membership in a regulated industry. From the existing studies; Yuan, Indrit and Ann (2019) results show a positive significant effect of foreign ownership on audit quality, while inverse significant effect of family ownership on audit quality. Franciele, 
Paulo, and Leandro (2015) findings reveal inverse insignificant relationship between family and non-family ownership and audit quality. Hartono, Subrato, Djumahir and Irianto (2013) findings of the study show that firm age has significant and negative effects on audit quality.

Furthermore, some of the studies revealed that client's size of business, international recognition; affiliation of audit firms (Big four firms) and profitability are significant determinants of audit fee such as the study of Alhassan, 2017; Agbeja and Sokunle, 2016; Bogale, 2016; Belen, Roberto \& Antonio, 2014; Chijioke, Adeyemi, Obehioye, 2013; Sharma, 2011; Bedard and Johnstone, 2008). On the other hand, some researchers found negative significant effect between audit fees and its determinants (see Hassan, 2014; Soyemi and Olowookere, 2013; Adeyemi, et.al, 2013; Hsieh, 2011; Siregar, et.al, 2012; Dehkordi and Makarem, 2011; Meshari, 2008).

The empirical evidences on the determinants of external audit fees are inconsistent and some are contradictory; ranging from positive, to negative effect. Besides, few research works have been conducted on Nigerian deposit money banks in particular; (Agbaje and Sokunle, 2016; Soyemi and Olowookere, 2013). It is against the above backdrop that the current study extends previous studies by presenting new evidence about the external audit fees determinants in Nigerian deposit money banks.

\section{METHODOLOGY}

\subsection{Research Design}

Ex-post facto research design was adopted for the study. This is appropriate because the study aims at measuring the relationship between one variable and another, in which the variables involved are not manipulated by the researcher.

\subsection{Population of the Study}

The population of the study consists of the 15 deposit money banks quoted on the Nigerian Stock Exchange. The study covered ten years annual reports and accounts of these banks from 2009 to 2018 as stated in the appendix 1.

\subsection{Determination of Sample Size}

The researcher intended to use all the deposit money banks for the study.

\subsection{Method of Data Analysis}

The data was sourced from publications of Annual Reports and Accounts of the sampled banks. The data extracted include; client complexity, and board size and audit fees.

The dependent variable is proxied using audit fees, while the independent variables are client complexity, and board size. Audit fees comprise the natural log of the Audit fees paid by the company. Multiple regression analysis was used to test the relationship between the independent 
Journal DOI: 10.46654/ij.24889849

Vol. 6, Issue 10 (October, 2020) | www.ijaar.org

Article DOI: 10.46654/ij.24889849.s61031

variables and the dependent variables. This was done with aid of the E-view version 9 at five degree of freedom (df).

\section{Decision Rule}

The decision for the hypotheses is to accept the alternative hypotheses if the p-value of the test statistic is less or equal than the alpha and to reject the alternative hypotheses if the p-value of the test statistic is greater than alpha at $5 \%$ significance level.

\section{Model Specification}

The specified simple regression estimated model takes the following form:

$\operatorname{AUDFES}_{\mathrm{it}}=\mathrm{a}_{0}+\mu_{\mathrm{i}}+\beta_{1} B O D S Z_{\mathrm{it}} \sum_{\mathrm{it}}$

AUDFES $_{\text {it }}=\mathrm{a}_{0}+\mu_{\mathrm{i}}+\beta_{3}$ CLTCOMP $_{\text {it }} \sum_{\mathrm{it}}$

Where:

AUDFES= Audit fees measured as the amount of fees charged by the auditor for an audit service and

$C L T C O M P=$ in this study we measured firm complexity by the number of branches a company operates.

$B O D S Z=$ Measured as the number of individuals on the board

$\mathrm{a}_{0}=$ slope of the model

$\beta_{\mathrm{I}}, \beta_{2}, \beta_{3},=$ coefficient of parameter.

\section{PRESENTATION AND ANALYSIS OF DATA}

\subsection{Data Analysis}

\section{Table 4.1: Descriptive Analysis}

$\begin{array}{lccc} & \text { AUDFES } & \text { BODSZ } & \text { CLTCOMP } \\ \text { Mean } & 259460.7 & 15.30000 & 267.5000 \\ \text { Median } & 257803.5 & 17.00000 & 293.0000 \\ \text { Maximum } & 350000.0 & 17.00000 & 298.0000 \\ \text { Minimum } & 135000.0 & 10.00000 & 178.0000 \\ \text { Std. Dev. } & 80758.48 & 2.945807 & 41.92917 \\ \text { Skewness } & -0.308010 & -1.216707 & -1.063571 \\ \text { Kurtosis } & 1.841521 & 2.687741 & 2.911031 \\ \text { Jarque-Bera } & 0.717315 & 2.507922 & 1.888604 \\ \text { Probability } & 0.698614 & 0.285372 & 0.388951 \\ \text { Sum } & 2594607 . & 153.0000 & 2675.000 \\ \text { Sum Sq. Dev. } & 5.87 \mathrm{E}+10 & 78.10000 & 15822.50 \\ \text { Observations } & 10 & 10 & 10\end{array}$

Source: researcher's computation (2020) 
Table 1 revealed the mean for each of the variables, their maximum values, minimum values, standard deviation and Jarque-Bera (JB) Statistics (normality test). The results provided some insight into the nature of the selected Nigerian quoted deposit money banks that were used in this study.

Firstly, it was observed that on the average over the ten years periods (2009-2018), the sampled quoted banks in Nigeria were characterized by positive audit fees (259460.7). Also, the large difference between the maximum and minimum value of the board size and client complexity show that the sampled quoted banks in this study are not dominated by with large audit fees.

\subsection{Test of Hypotheses}

$\mathrm{Ho}_{1}$ : Board size has no significant effect on audit fees of Nigerian deposit money banks. $\mathrm{Ho}_{2}$ : Client complexity has no significant effect on audit fees of Nigerian deposit money banks.

Table 2: Ordinary Least Square test between audit fees, board size and client complexity Dependent Variable: AUDFES

Method: Least Squares

Date: 10/27/20 Time: 15:30

Sample: 20092018

Included observations: 10

\begin{tabular}{lrlrr}
\hline \hline \multicolumn{1}{c}{ Variable } & Coefficient & Std. Error & t-Statistic & Prob. \\
\hline \multicolumn{1}{c}{ C } & -177022.2 & 86431.65 & -2.048117 & 0.0798 \\
BODSZ & 16628.94 & 6711.469 & 2.477690 & 0.0424 \\
CLTCOMP & 680.5984 & 471.5259 & 1.443396 & 0.1921 \\
\hline \hline R-squared & 0.809583 & Mean dependent var & 259460.7 \\
Adjusted R-squared & 0.755178 & S.D. dependent var & 80758.48 \\
S.E. of regression & 39958.86 & Akaike info criterion & 24.27241 \\
Sum squared resid & $1.12 \mathrm{E}+10$ & Schwarz criterion & 24.36319 \\
Log likelihood & -118.3621 & Hannan-Quinn criter. & 24.17283 \\
F-statistic & 14.88073 & Durbin-Watson stat & 0.670611 \\
Prob(F-statistic) & 0.003013 & & \\
\hline \hline
\end{tabular}

Board size: based on the t-value of 2.477690 and p-value of 0.0424 was found to have a positive influence on our sampled quoted banks audit fees and this influence is statistically significant at $5 \%$ level since its p-value is more than 0.05 value. This result therefore suggests that we reject our null hypothesis (Ho) and uphold alternative which states that board size has significant effect on audit fees of Nigerian deposit money banks.

Client complexity: based on the t-value of 1.443396 and p-value of 0.1921 was found to have a positive influence on our sampled quoted banks audit fees and this influence is not statistically significant at $5 \%$ level since its p-value is more than 0.05 value. This result therefore suggests that we reject our alternative hypothesis $(\mathrm{Ho})$ and uphold null which states that client complexity has no significant effect on audit fees of Nigerian deposit money banks. 


\subsection{Discussion of Findings}

Findings revealed that client complexity, and board size has positive influence on audit fees of Nigerian deposit money banks but the influence on board size is statistically significant while client complexity was insignificant. This result is in line with that of Alhassan (2017); Bogale (2016) study reveals that client's size of business, international recognition; affiliation of audit firms (Big four firms) and profitability are significant determinants of audit fee. Also Urhoghide and Izedonmi (2015). The results for audit client characteristics revealed that audit client size and complexity have a positive and significant impact on audit fee while profitability, fiscal year end and industry have a negative and significant influence on audit fee.

\section{CONCLUSION AND RECOMMENDATION}

Based on analysis, the findings revealed that client complexity, and board size have positive influence on audit fees of Nigerian deposit money banks but the influence on board size is statistically significant while client complexity was insignificant. This outcome is similar to that obtained by numerous audit fee research performed in several countries. Moreover, the results revealed that the amount of audit fees is positively related to the profitability and client size. This finding leads to the assumption that better-off audit clients might be viewed to have a "deeper pocket," and so are charged higher amounts of external audit fees.

A rationale for this could be that, in Nigeria rules and regulations are not strict and hard like developed countries where mostly auditors are held liable and punished for manipulation of accounting figures. Furthermore, these results also show that the concern about audit independence impairment derived from high external audit fees is reasonable.

Based on the results of the findings, and conclusions derived therein, the following recommendations are made:

The client's firm size should be used as a major criterion in the determination of audit fees in Nigeria. Government regulating agencies should see to the issue of audit fees charged by auditors for engaging in audit exercise. It should be clearly reviewed and documented under the section in the Companies and Allied Matters Act that is concerned with the remuneration of the auditors of a firm. 


\section{References}

Abiola, J. \& Asiweh, M. (2012). Impact of tax administration on government revenue in a developing economy - A Case Study of Nigeria International Journal of Business and Social Science 3(8)[Special Issue - April 2012] 99

Agbeja, O. \& Sokunle, O.T (2016).An assessment of the role of external auditor in the detection and prevention of fraud in deposit money banks in Nigeria (2005-2014). International Academic Journal of Accounting and Financial Management 3(1), pp. 13-36. ISSN 2454235013 www.iaiest.com.

Alhassan M. (2017). Determinants of audit fees in a developing economy: Evidence from Ghana International Journal of Academic Research in Business and Social Sciences 2017, 7(11) ISSN: 2222-6990 716 www.hrmars.com.

Al-Harshani, M. O. (2008). The pricing of audit services: evidence from Kuwait. Managerial Auditing Journal, 23(7), 685-696.

Al-Shammari, B., Brown, P., \& Tarca, A. (2008). An investigation of compliance with international accounting standards by listed companies in the Gulf Co-Operation Council member states. The International Journal of Accounting, 43(4), 425-447.

Aliu, M. M., Okpanachi, J. \& Mohammed, N. A. (2018). Audit fees and audit quality: a study of listed companies in the downstream sector of Nigerian petroleum industry. Humanities and Social Sciences Letters. 6 (2), 59-73. DOI: 10.18488/journal.73. 62.59.73

Ahmed, K. \& Goyal, M. (2005). A comparative study of pricing of audit services in emerging economies. International Journal of Auditing, 9,103-116. http://dx.doi.org/10.1111/j.1099-1123.2005.00236.

Ask, J., \& LJ Holm, M. (2013). Audit fee determinants in different ownership structures: The Swedish Setting. Master thesis in Accounting Auditing and Business Analysis. UPPSALA University Diva-potal.

Augustine, O. E., Chijioke, M., Adeyemi, A., Obehioye U. \& Ehi-O. (2013). Determinants of Audit Quality in the Nigerian Business Environment. Research Journal of Finance and Accounting Vol.4, pp. 36-43

Abdul, H., Sutrisno, T., Rosidi, \& Achsin, M. (2014). Effect of competence and auditor independence on audit quality with audit time budget and professional commitment as moderation variable. International Journal of Business and Management Invention.3(6), 64- 74.

Abu Bakar, N., Abdul Rahman, A., \& Abdul Rashid, H., (2005). Factors influencing auditor independence: Malaysian loan officers' perceptions", Managerial Auditing Journal, vol 20, pp,804-822.

Bedard, J. C., \& Johnstone, K. M. (2010). Audit partner tenure and audit planning and pricing. Auditing: A Journal of Practice \& Theory, 29(2), 45-70.

Bogale, A. (2016). Determinants of external audit quality: evidence from manufacturing share companies in Addis Ababa Ethiopia. A Thesis Submitted to the Department of Accounting and Finance, College of Business and Economics Presented in the Partial Fulfillment for the Requirement in Master's Degree in Accounting and Finance.

Beasley, M. S. (1996). An empirical analysis of the relation between the board of director composition and financial statement fraud. The Accounting Review (October), 443-465. 
Boo, E., \& Sharma, D. (2008). Effect of regulatory oversight on the association between internal governance characteristics and audit fees. Journal of Accounting and Finance, 48(1), 5171.

Causholli, M., De Martinis, M., Hay, D., \& Knechel, W. R. (2011). Audit markets, fees and production: Towards an integrated view of empirical audit research. Available on Research Gate.

Castro, W. B. D. L., Peleias, I. R., \& Silva, G. P. D. (2015). Determinants of audit fees: a study in the companies listed on the BM\&FBOVESPA, Brazil. Revista Contabilidade \& Finanças, 26(69), 261-273.

Callaghan, H., Parkash, M., \& Singhal, R. (2008). The impact of the multi-jurisdiction disclosure system on audit fees of cross-listed Canadian firms. The International Journal of Accounting, 43 (2008), 99-113. http://dx.doi.org/10.1016/j.intacc.2008.04.001.

Carson, E., Fargher, N., Simon, T., \& Taylor, .H. (2004). Audit fees and market segmentation further evidence on how client size matters within the context of audit fee models. International Journal of Auditing, 8, 79-91 http://dx.doi.org/10.1111/j.10991123.2004.00159.x

Choi, H., Kim, C., Jeong, B., \& Zang, Y. (2010). Audit office size, audit quality, and audit pricing. Auditing: A Journal of Practice \& Theory, American Accounting Association, 29(1), 73-97. http://dx.doi.org/10.2139/ssrn.1011096

Che- Ahmed, A., \& Houghton, K. A. (1996). Audit fees premium to big eight firms: evidence from the medium-size UK auditees. Journal of International Accounting, Auditing and Taxation. 5(1), 53-72.

Collier, P. \& Gregory, A. (1996). Audit committee effectiveness and the audit fees. The European Accounting Review, 5(2), 177-198.

Dehkordi, H. F., \&Makarem, N. (2011). The effect of size and type of auditor on audit quality.International Research Journal of Finance and Economics, vol. 80, pp. 121-137.

De, Angelo, L. E., (1981). Auditor size and audit quality: Journal of Accounting and Economics, Vol. 3, pp.183-199.

Dillian, C. M. L. (2007). How a company's level of corporate governance affects external audit fees? , Hong Kong Baptist University.

Dugar, A., Ramanan, R., \& Simon, D. T. (1995). A comparative study of the audit services market for public sector versus private sector companies in India. Advances in International Accounting, 10, 1-13.

Chinwe, C.A. \& Chinwuba, O. (2012). Auditors independence, auditors' tenure and audit firm size in Nigeria. Research Journal of Finance and Accounting, 3(10), 137-142.

Dopuch, N. D., King, R. R., \& Schwartz, R. (2001). An experimental investigation of reputation and rotation requirements. Journal of Accounting Research, 39(1), 93-117.

Ettredge, M., Heintz, J. Li, C. \& Scholz, S. (2008). Auditor realignments accompanying implementation of SOX 404 reporting requirements. Working paper, University of Kansas.

Francis, (2004). A Framework for Understanding and Researching Audit Quality, Auditing: A Journal of Practice \& Theory, vol. 30, pp.125-152.

Fleischer, R., \& Goettsche, M. (2012). Size effects and audit pricing: Evidence from Germany. Journal of International Accounting, Auditing and Taxation, 21(2), 156-168. 
Gonthier, B., \& Schatt, A. (2007). Determinants of audit fees for French quoted firms. Managerial Auditing $\quad$ Journal, 22(2), 139-160. http://dx.doi.org/10.1108/02686900710718654.

Gist, E., (1992). Explaining variability in external audit fees. Accounting and Business Research, 23(89), 79-84.http://dx.doi.org/10.1080/00014788.1992.9729863.

Goddard, A. R \& Masters, C. (2000). Audit committee, cadbury code and audit fees: An empirical Analysis of UK companies. Managerial Auditing Journal, 15(7), 358-371.

Hassan, Y. K., (2015). Determinants of audit fees: evidence from Jordan. Accounting and Finance Research 4(1); 2015 Published by Sciedu Press 42 ISSN 1927-5986 E-ISSN 1927-5994 www.sciedu.ca/afr

Hentati, E., \& Jilani, F. (2013). The determinants of non-audit fees in French firms. Management Science Letters, 3(6), 1773-1782.

Hsieh, M. T. (2011). Does audit partner tenure influence on audit quality? Asian Journal of Management, vol.8, pp. 11-26.

Hay, D. C., Knechel, W. R., \& Wong, N. (2006). Audit fees: a meta-analysis of the effect of supply and demand attributes. Contemporary accounting research, 23(1), 141-191.

Ho, S. \& Hutchinson, M. (2010). Internal audit department characteristics/activities and audit fees: Some evidence from Hongkong firms, Journal of International Accounting Auditing and Taxation, 19(2), 121-136.

Hoitash, R., Markelevich \& Barragato, C. (2007). Auditor fees and audit quality. Managerial Auditing Journal. 22(8). DOI: 10.1108/02686900710819634.

Hartono, U., Subroto, B., Djumahir, T \& Irianto, G. (2013). Firm characteristics, corporate governance and firm value. International Journal of Business and Behavioral Sciences, 3(8). PP. 9-18.

ICAS, (2014). Influence of auditor independence, audit tenure and audit fee on audit quality of members of capital market accountant forum in Indonesia. Procdia-Socialand Behavioural Sciences. 164, 324-331.

Joshi, P. L., \& Al-Bastaki, H. (2000). Determinants of audit fees: evidence from the companies listed in Bahrain. International journal of auditing, 4(2), 129-138.

Kikhia, H. Y. (2014). Determinants of audit fees: evidence from Jordan. Accounting and Finance Research, 4(1), 42.

Kwong, J. (2011). The relationship between industry specialization and the audit fee premium in New Zealand. International Journal of Business and Social Science, 2(4).

Meshari, O. (2008). The pricing of audit services: evidence from Kuwait. Managerial Auditing Journal, 23(7), 685 -696. http://dx.doi.org/ 10.1108/02686900810890643.

Moizer, P. (1997). Auditor reputation: the international empirical evidence. International Journal of Auditing, 1(1),61-74. http://dx.doi.org/10.1111/1099-1123.00013

Nam, S., \& Ronen, J. (2014). The impact of non audit services on capital markets. Journal of Accounting, Auditing \& Finance. 27,32-60.

Naser, K., \& Nuseibeh, R. (2008). Determinants of audit fees: empirical evidence from emerging economy'.International Journal of Commerce and Management, 17 (3), 239-254.

Naser, A. A. K., Al-Mutairi, A., \& Rana Nuseibeh, K. (2013). Can substitution and signaling theories explain the relationship between external audit fees and the effectiveness of internal corporate governance?. Global Journal of Management and Business Research, $13(5)$. 
Naser, K., \& Al-Khatib, K. (2000). Determinants of the depth of information disclosure in the board of directors' statements of a sample of Jordanian listed companies. Advances in International Accounting, 13, 99-118.

Niskanen, M., Karjalainen, J. \& Niskanen, J. (2010).The role of auditing in small, private family firms: is it about quality and credibility?. Family Business Review, 23 (3), 230-245.

Ohidoa, T. \& Okun, O. O. (2018). Firm's attributes and audit fees in Nigeria quoted firms. International Journal of Academic Research in Business and Social Sciences, 8(3), 685699.

Paino, P. H., \& Tahir, W. M. M. W. (2012). Financial reporting risk assessment and audit pricing. In Business, Engineering and Industrial Applications (ISBEIA), 2012 IEEE Symposium on (pp. 85-89). IEEE.

Pong, M. (2004). A descriptive analysis of audit price changes in the UK 1991-95. European Accounting Review, 13(1)161-178. http://dx.doi.org/10.1080/0963818032000134921

Robert Knechel, W. \& Vanstraelen, A. (2007). The relationship between auditor tenure and audit quality implied by going concern opinions: A journal of practice \& theory Vol. 26, pp. $113-131$.

Siddiqui, J., Zaman, M., \& Khan, A. (2013). Do Big-Four affiliates earn audit fee premiums in emerging markets?. Advances in Accounting, 29(2), 332-342.

Shafie R., Hussin W., Yusof .M \& Hussain M. (2009). Audit firm tenure and auditor reporting quality: evidence in Malaysia.

Shivaram, R. Suraj, S. \& Xin, Z. (2015). Measuring audit quality, Journal of Accounting and Economics 24(1): 3-37

Shafie, R., Che Ahmad, A., \& Md Ali, A. (2007). The relationship between non-audit service fees and audit fees in the banking sector in Malaysia. International Journal of Management Studies (IJMS), 14(1), 61-87.

Simunic, D. A. (1980). The pricing of audit services: theory and evidence'. Journal of Accounting Research, 22 (3), 161-190.

Sharma, V. D., (2011). Non-audit services and knowledge spillovers. evidence from Tunisian manufacturing companies: Journal of Business Finance \& Accounting, vol. 6, pp. 23-58.

Simon, D. T., \& Taylor, M. H. (2002). A survey of audit pricing in Ireland. International Journal of Auditing, 6(1), 3-12.

Siregar, S. V., Amarullah, F., Wibowo, A., \& Anggraita, V. (2012). Audit tenure, auditor rotation and audit quality: The case of Indonesia. Asian Journal of Business and Accounting, vol. 5, pp. 55-74.

Soyemi, K. A. \& Olowookere, J. K. (2013).Determinants of external audit fees: evidence from the banking sector in Nigeria. Research Journal of Finance and Accounting 4(15). ISSN 2222-1697 (Paper) ISSN 2222-2847 (Online) www.iiste.org

Sandra, W. M. H., \& Patrick, P. H. N. (1996). The determinants of audit fees in Hong Kong: An Empirical Study'. Asian Review of Accounting, 4(2), 32-50. http://dx.doi.org/10.1108/eb060673

Semiu, B. A. \& Olayinka, M. U.(2010). The impact of firms' characteristics on audit fees, Nigeria Journal of Management Studies, 10(2), 4-10.

Steward, J. \& Munro, L. (2007). The impact of audit committee existence and Audit committee meeting frequency on the external audit: Perceptions of Australian auditors. International Journal of Auditing. 11, 51-69. 
Sundgren, S., \& Svanström, T. (2013). Audit office size, audit quality and audit pricing: evidence from small-and medium-sized enterprises. Accounting and Business Research, $43(1), 31-55$.

Shan, Y. G (2012). The impact of internal governance mechanisms on audit quality: A study of large listed companies in China. Business School, University of Adelaide, Adelaide, Australia.

Thinggaard, F. \& Kiertzner, K., 2008. Determinants of audit fees: evidence from a small capital market with a Joint Audit Requirement. International Journal of Auditing Int. J. Audit. 12,141-158. http://dx.doi.org/10.1111/j.1099-1123.2008.00377.x

Urhoghide, R. O. \& Izedonmi, F. O. I. (2015). An empirical investigation of audit fee determinants in Nigeria. International Journal of Business and Social Research. 5(8).

Vermeer, T. E., Raghunandan, K., \& Forgione, D. A. (2009). Audit fees at US non-profit organizations. Auditing: A Journal of Practice \& Theory, 28(2), 289-303.

Vafeas, N. \& Waegelein, J. (2007). The association between audit committees, compensation incentives, and corporate audit fees. Review of Quantitative Finance and Accounting, 28 (3), 241-255.

Watts, R. \& Zimmerman, J. (1986). Positive accounting theory. Prentice-Hall, Englewood Cliffs, NJ.

Walid, G. (2012). Determinants of Audit Fees: Evidence from Lebanon, International Business Research; 5(11), 2012. http://dx.doi.org/10.5539/ibr.v5n11p136.

XU, J. Z. Y. (2005). The determinants of audit fees: evidence from the China's Listed Companies in 2001-2003 [J]. China Accounting Review, 1(006).

Yatim, P., Kent, P. \& Clarkson, P. (2006). Governance structures, ethnicity, and audit fees of Malaysian Listed Firms. Managerial Auditing Journal, 21(7), 757-782.

Yuan, G. S. Indrit, T. \& Ann,T. (2019). Audit report lag, audit fees, and audit quality following an audit firm merger: Evidence from Hong Kong. Journal of International Accounting, Auditing and Taxation, V.36, 100271 
International Journal of Advanced Academic Research (Social and Management Sciences) | ISSN: 2488-9849

Vol. 6, Issue 10 (October, 2020) | www.ijaar.org

Journal DOI: 10.46654/ij.24889849

Article DOI: 10.46654/ij.24889849.s61031

\section{Appendix 1}

\begin{tabular}{|l|}
\hline Access bank plc \\
\hline Diamond bank plc \\
\hline First bank plc \\
\hline FCMB plc \\
\hline GTB plc \\
\hline Zenith bank plc \\
\hline Sterling bank plc \\
\hline UBA plc (M) \\
\hline Fidelity bank plc \\
\hline Wema bank plc \\
\hline Unity bank plc \\
\hline Eco bank plc \\
\hline Union bank plc \\
\hline Skye bank plc \\
\hline Stanbic IBTC \\
\hline
\end{tabular}

